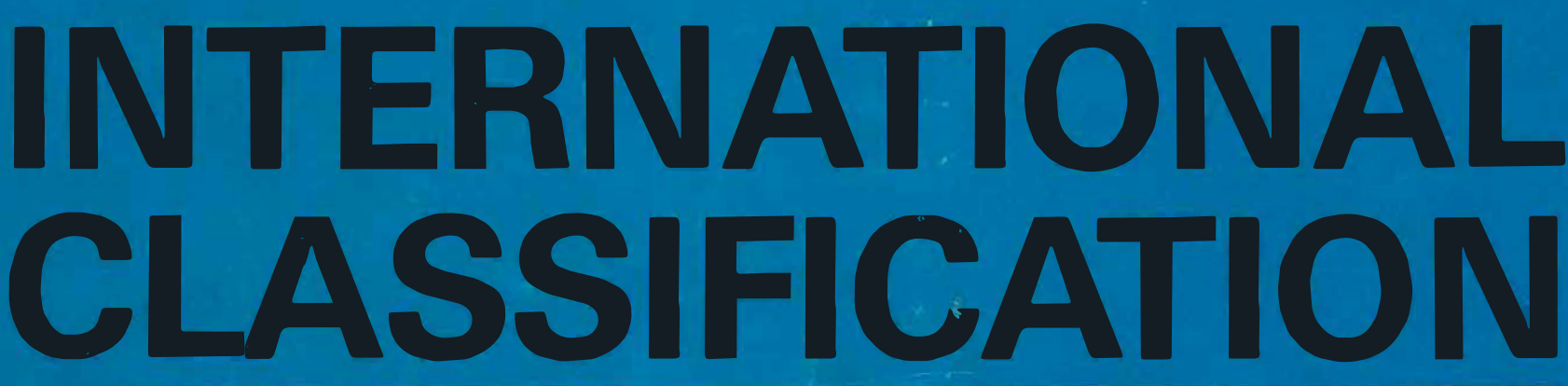

Journal on Theory and Practice of Universal and Special Classification Systems and Thesauri Zeitschrift zur Theorie und Praxis universaler und spezieller Klassifikationssysteme und Thesauri

Editors/Herausgeber

Dr.I. Dahlberg, Frankfurt, BRD (Editor-in-Chief)

Prof. Dr. Dr. A. Diemer, Düsseldorf, BRD

Prof. A. Neelameghan, Bangalore, India

Prof. J.M. Perreault, Huntsville, Ala., USA

in collaboration with/in Zusammenarbeit mit

Prof. P. Atherton, Syracuse, N.Y., USA

Dipl.Math. H. Fangmeyer, Ispra, Italy

Prof. E. de Grolier, Paris, France

Dr. F. Lang,Vienna, Austria

Prof. Dr. D. Soergel, College Park, Md., USA

Prof. B.C. Vickery, London, England

and the Research Department Information and Documentation

of the Philosophical Institute, University of Düsseldorf

(Director: Prof. Dr. N. Henrichs)

Verlag Dokumentation, Pullach b. München

Intern.Classificat.1(1974) No.1, p.1-58 - Pullach b. München, May 1974 


\section{Contents - Inhalt}

\section{INTERNATIONAL CLASSIFICATION}

Editorial

Why this Journal?

Articles - Aufsätze

B. M. Kedrov: Concerning the Synthesis of the Sciences . . . . . 3

I. Dahlberg: Zur Theorie des Begriffs (Towards a theory of the concept) 12

V. Rybatchenkov: Development of a Broad System of Ordering

for UNISIST Purposes . . . . . . . . . . . . . . . . 20

E. Wåhlin: A Common Classification for Swedish Research Projects . 21

A. J. Mayne: Progress Report on a New Scheme for the Classification

of Knowledge . . . . . . . . . . . . . . . . . . 27

M. E. Neuenschwander: Systeme der Waren- und Aktivitätsklassifikation (Systems for the Classification of Commodities and Activities) . D. Soergel: Automatic and Semi-Automatic Methods as an Aid in the Construction of Indexing Languages and Thesauri . . . . . 34

Reports and Communications

A. Neelameghan: Classification Research and Development in India, 1968-1974 . . . . . . . . . . . . . . . . . 39

H. Fangmeyer: Automatic Classification and Indexing . . . . . 40

K. Ostarhild: Ordnungssysteme für Warendaten . . . . . . . . 41

O. Gekeler: Warenkatalogisierung und Kommunikation über die Ware

(Commodity Cataloguing and Communication) . . . . . . . . 42

J. M. Connor: Commodity Classification and Naming, their role in information systems . . . . . . . . . . . . . . . . . 43

W. de Regt: Symposium on Multilingual Thesauri . . . . . . . 43

INER Kolloquium No. VIII . . . . . . . . . . . . . . . . . . 44

Symposium über den Wissenschaftsbegriff in Hannover . . . . . 44

Wissenschaftssprache - Umgangssprache . . . . . . . . . . 44

The Classification Society . . . . . . . . . . . . . . . 45

News - Nachrichten . . . . . . . . . . . . . . . . 45

Book Reviews - Buchbesprechungen

Maltby, A. (Ed.): Classification in the 1970's ... (by J. M. Perreault) . 47

Classification Literature 1 (1974) No. 1, Nos. 001-521 . . . . . 49

Bibliographies - Literature Reviews - Classification Systems and

Thesauri - Dictionaries - Proceedings - Periodicals and Serials

(1)

.

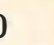

7

32

34

1

2

3

.


Journal on Theory and Practice of Universal and Special Classification Systems and Thesauri Zeitschrift zur Theorie und Praxis universaler und spezieller Klassifikationssysteme und Thesauri

Publisher: Verlag Dokumentation Saur KG, D-8023 Pullach b. München, Jaiserstr. 13, POB 148, BRD

Tel.: (089) 793 2121, Telex: 5212067 saur d

Editorial offices: c/o Dr. I. Dahlberg, D-6000 Frankfurt 50, Woogstr. 36a, BRD, Tel.: (0611) 523690

Issue frequency/Erscheinungsweise: 2/ann.; Subscription/Preis: DM 36,-/ann.

\section{Contents page - Inhaltsfahne}

This contents page may be reproduced without charge - Diese Inhaltsfahne darf gebiihrenfrci vervielfältigt werden (DIN 1428)

Kedrov, B. M.: Concerning the Synthesis of the Sciences. In: Intern. Classificat. 1 (1974) No. I, p. 3-11; also in: USSR Academy of Sciences (Ed.): Man, Science, Technology. I. Moscow 1973. p. 67-92 = Social Sciences Today. Editorial Board.

A presentation of types of processes leading to a theoretical synthesis of contemporary scientific knowledge, e. g. a synthesis by law, by correspondence, or by opposition. Internal interbranch synthesis can be observed in four phenomena: 1) formerly, the sciences developed by differentiation, now by their integration; the other phenomena are: 2) "cementation", 3) "fundamentalization and 4) pivotization" of sciences. External synthesis is seen in the relationships existing respectively between 1) natural and social sciencos, 2) natural and technological sciences, and 3 ) natural sciences and philosophy. The various types of processes discussed are displayed in a table.

Dahlberg, I.: Zur Theorie des Begriffs. (Towards a theory of the concept)

In: Intern. Classificat. 1 (1974) No. 1, p. 12-19 (in German)

A concept is regarded as the common element of both classification systems and thesauri. Reality and knowledge are not represented by words or terms but by the meanings "behind" these tokens. A concept of, say, an object, a property of an object, a process, etc. is derived from verbal statements on these as subjects and may therefore be defined as the whole of true and possible predicates that can be collected on a given subject. It is from these predicates that the characteristics of the corresponding concepts can be derived. Common characteristics in different concepts lead to relations between concepts, which relations in turn are factors for the formation of concept systems. Different kinds of relationships as well as different kinds of concepts are distinguished. It is pointed out that an orderly supply of the elements for propositions (informative statements) on new knowledge requies the construction and availability of such concept systems.

(Author)

Rybatchenkov, V.: Development of a Broad System of Ordering for UNISIST Purposes

In: Intern. Classificat. 1 (1974) No. 1, p. 20-21

Outline of the functions of a Broad System of Ordering (BSO) as a switching mechanism in the UNISIST Program of Unesco. Co-operation with the Fédération Internationale de Documentation (FID), Den Haag, which in 1972 has set up for the elaboration of a Subject-field Reference Code (SRC) a Working Group (FID/SRC). Structure, notation and display of the SRC as result of the first year's discussions are mentioned as well as the use of existing experience and the future work as planned for 1974 .

(I. C.)
Wåhlin, E.: A Common Classification for Sivedish Research Projects.

In: Intern. Classificat. 1 (1974) No. 1, p. 21-26

Proposal for a universal classification system on the level of subject-fields based on the observation of a continuous interdisciplinary combination of former single subject-fields. Thc multitude of possible combinations is shown in a "discipline matrix" of the natural sciences and technology. For the interdisciplinary field of ecology a "geometrical display" is used, showing possible combinations of natural objects with each other and in relation to their respective fields. Concludingly the difficulty in indexing research projects is pointed out.

(I. C.)

Mayne, A. J.: Progress Report on a New Scheme for the Classification of Knowledge.

In: Intern. Classificat. 1 (1974) No. 1, p. 27-32

Outline of the theory of a proposed new scheme of classification of knowledge, specifying its basic assumptions and its points of departure from existing schemes, describing possible mathematical models for the scheme, and indicating the mnemonic notation and coding proposed. Progress is reported on the development of applications of the scheme to general and special library classifications and to the document collections of small organisations, groups and individuals. Possibilities for future research arc outlined and further potential applications are listed. (Author)

Neuenschwander, M.E.: Systeme der Waren- und Aktivitätsklassifikation. (Systems for the classification of commodities and activities)

In: Intern. Classificat. 1 (1974) No. 1, p. 32-33 (in German)

To acquire a better survey of existing ordering systems for commodity classification, 3 different types of such systems are listed according to the different purposes they are intended to serve. They include supply-oriented systems for statistics and systems for the cataloguing of commodities in companies and administrative services, in the latter only commodities actually on the market are included.

Soergel, D.: Automatic and Semi-Automatic Metlods as an Aid in the Construction of Indexing Languages and Thesauri. In: Intern. Classificat. 1 (1974) No. 1, p. 34-39

Development of a framework for the description and classification of statistical and graph-theoretical methods for the determination of terms and concepts and of relationships bctween and among them. Discussion of the problem of terms versus concepts in this context, the 'units of text' to be used for these methods, total count versus unitwise count, and practical problems of data collection. Brief characterization of methods for the use of 1) frequency data in descriptor sclection, 2) co-occurrence data to determine terminological relationships between concepts, 3) binary relationships detected in the previous step to construct global classificatory structures.

(Author) 


\section{The Publisher's Practical Dictionary in 20 Languages}

Edited by Dr. Imre Móra. 389 pages. ISBN 3-7940-4112-7. DM 88.00

Whether you want discuss steps in book production, translate important technical expressions in music publishing, or agree on broadcasting, television, recording on films rights in a publishing contract, THE PUBLISHER'S PRACTICAL DICTIONARY makes it easy for you and your colleagues in foreign countries to understand each other. This new dictionary gives you a total working vocabulary of some 18,000 basic terms and phrases.

\section{0,000 sources for information ahout science all over the world! World Guide to Scientific Associations}

Handbook of International Documentation and Information, Volume 13 1974. ISBN 3-7940-1013-2. 481 pages. DM 98.00

This handbook contains more than 10,000 associations and groups from all fields of science and research in 134 states of all five continents. In addition to this all academies, organizations of physicians and teachers have been listed. The associations are organized by continents, then by countries and finally in mechanical alphabetical order. Each entry contains the name of the association, the abbreviation if known, the year of foundation and the address. Postal codes are given if the country in question has such a system. A detailed subject index gives information on functions and subject arca for the associations with complete names.

\section{Here are 26,000 trade- and industry-related organizations from every corner of the world! World Guide to Trade Associations}

Handbook of International Documentation and Information, Volume 12 1973. ISBN 3-7940-1012-4. 1,500 pages. DM 148.00 per two-volume-set

Complying with often-repeated requests from trades and agencies, we have decided to present to all those interested in the World Guide to Trade Associations a practical guide to associations with their addresses and phone numbers. Part 1 of this handbook contains some 15,000 addresses of European trade associations. Vol. 2 lists more than 11,000 associations in the U.S.A. and in non-European countries.

The handbook includes national and international organizations and associations of trades such as chambers of commerce and crafts, professional organizations, consumer organizations, employers' and employees' groups and organizations of the service professions.

\section{New 6th edition - higger, hetter, more comprehensive than ever! Publisher's Intemational Directory}

Handbook of International Documentation and Information, Volume 7. 6th edition. 1974. ISBN 3-7940-1270-4. Subscription price DM 138.00 with supplement. Final list price approx. DM 160.00 with supplement.

This new 6 th edition lists more than 20,000 publishers from far more than 150 countries in geographical arrangement by continent and country. In addition to the publisher's name and address, each listing contains abbreviations which indicate the subject specialities. 59 different areas are included, such as arts, history, education, science, directories, and so on. Entries are indexed by subject specialities with cross-references and by country. The supplement includes all publisher identifiers (ISBN) in numerical as well as in alphabetic order. 